\title{
WHO USES A MOBILITY CARD? A CASE STUDY ON THE WIENMOBIL CARD
}

\author{
C. LINK$^{1}$, A. HEINEMANN ${ }^{1}$, R. GERIKE ${ }^{2}$, H. JONUSCHAT ${ }^{3} \&$ M. MARYSCHKA ${ }^{4}$ \\ ${ }^{1}$ Institute for Transport Studies, University of Natural Resources \\ and Life Science (BOKU), Vienna, Austria. \\ ${ }^{2}$ Institute for Integrated Transport Planning and Traffic Engineering, \\ Technical University (TU) Dresden, Germany. \\ ${ }^{3}$ InnoZ GmbH, Berlin, Germany. \\ ${ }^{4}$ WienIT, Vienna, Austria.
}

\begin{abstract}
Cheap, fast, comfortable and environmental-friendly - people travelling inter- or multimodal can utilize the advantages of different transport modes by selecting or combining those which best meet their specific requirements in terms of trip purposes or travel patterns. However, there are barriers to inter- or multimodal travel behaviour. Mobility cards such as the WienMobil card might be the solution to break some of them. They enable to use several mobility services and modes of transport. The WienMobil card was introduced in spring 2015 and combines an annual PT ticket and access to both - a bike- and carsharing scheme. Additionally cardholders can use it to pay for taxi rides as well as get discounts for certain services like using the airport express train, for charging electric vehicles and for using urban car park facilities. The impacts of the WienMobil card are currently analysed in the project Guide2Wear using a pre-post-control-group approach. It includes a Web survey and two GPS-tracking periods, each covering an entire week. This article describes the first users of the WienMobil card, the so-called lead users with regard to socio-demographics, their mobility behaviour as well as their mobility-related expectations and requirements. The control group consists of annual PT ticket owners. The lead users are younger, more often male and have an above-average education level. Their mobility behaviour can be marked as more multimodal already before they used the WienMobil card. However, differences are even more pronounced in terms of perceived and real mobility behaviour. Considering attitudes towards public transport, there are no clear group differences.
\end{abstract}

Keywords: intermodality, lead users, mobility behaviour, mobility card, multimodality, public transport.

\section{INTER-AND MULTIMODALITY}

Cheap, fast, comfortable and environmental-friendly - people travelling inter- or multimodal can utilize the advantages of different modes of transport by selecting or combining those which best meet their specific requirements in terms of trip purposes or travel patterns. Some authors have already recognized a paradigm shift within the transport sector towards interand multimodal mobility behaviour. According to the most basic definitions, intermodality means that at least two transport modes are combined on a trip. Multimodal mobility behaviour refers to the use of different transport modes, but only one per trip [1].

In more detail, the distinction between mono-, inter- and multimodality mainly depends on the thresholds used. First of all, there is a major impact of the length of the observation period. If this period is long enough, nearly everybody will be multimodal. Another timerelated aspect is how to define a trip. Is a stop of five minutes - e.g. to buy a newspaper on a commuter trip while waiting for a bus - enough to divide one trip into two single trips (home \footnotetext{
This paper is part of the proceedings 22nd International Conference on Urban Transport and the
Environment (Urban Transport 2016)

www.witconferences.com
} 
- kiosk, kiosk - working place) and is it thus an intermodal trip or multimodal mobility behaviour if the kiosk was reached walking? Are walking trips to be considered at all - does a walk to a tram station make the trip intermodal? - which would make nearly every trip an intermodal trip, and are different public transport modes to be summarized? Apart from these definitions, there is a consensus that inter- and multimodal mobility are already gaining or are at least expected to gain in importance [2,3].

Decisive factors for this development are changes of the relevant framework conditions with technical and organizational aspects as the most important ones. 'Technical' refers most of all to the new opportunities provided by smartphones and continuous Internet connections. They allow new services in terms of information provision, route or transport mode selection, navigation or ticketing in real time. In this context, opportunities resulting from infrastructure-infrastructure, as well as user-infrastructure and user-user communication have to be mentioned. The smartphone reduces the complexity and difficulty to gather all information needed when travelling inter- or multimodal. 'Organisational' summarizes aspects such as the availability of sharing systems for both, cars and bicycles [4], but also a changed awareness of relevant stakeholders concerning environmental-friendly mobility. Further aspects supporting inter- and multimodality are the ongoing urbanization and a higher willingness to share a vehicle among the population which makes sharing schemes possible.

However, there are still barriers to inter- or multimodal travel behaviour. Among the most important ones are access burdens. This includes the need to be member of one or several car or bikesharing schemes and to buy tickets for public transport. Particular barriers to intermodal mobility behaviour on long-distance trips are missing information on intermodal services, the quality of interchanges, the connection between long-distance and local transport, as well as unclear ticketing systems [5].

\section{MOBILITY CARDS}

Mobility cards might be the solution to the problem of limited access to mobility options. These cards allow their holders to use several mobility services and modes of transport. Mobility cards belong to the group of horizontal integrated services since they incorporate several modes instead of several functions for one mode.

Although they seem to be anachronistic for some people, mobility cards have two major advantages compared to app-based solutions. First of all, everybody - particularly persons without smartphones - can buy and use them. Additionally, it is not an easy task to combine demands, concerns and requirements of several mobility providers. A smartphone-based approach makes this process even more complex since problems with data protection or technical interfaces have to be solved.

In the meantime, there are several mobility cards available throughout Europe. However, their impacts were only rarely analysed. An example of a mobility card is the oMnibus card in Brescia, Italy. This electronic card allows its users to pay parking fees, rent a bike or use public transport [6]. The Utrecht Accessibility Pass was introduced in 2009. It is a public transport card for commuters, allowing use of public transport, bikesharing, commuter busses and park-and-ride facilities. The card was not only one of the first of its kind but is also particularly successful. More than 20.000 cards were sold by the end of 2012 with significant impacts on the number of cars during rush hours [7]. 'Mobil in Düsseldorf' includes not only unlimited use of public transport for the cardholder and up to two accompanying persons on weekends and at evenings, four hours of bike use per day, but also 90 min carsharing per day. The monthly price is above 80 euros which makes the card not an option for spontaneous intermodality [8]. Switchh in Hamburg is not a mobility card, but a smartphone application 
which not only includes a public transport ticket but also provides access to bike- and carsharing schemes [9].

The WienMobil card was introduced as mobility card for Vienna in spring 2015. It is an electronic card comparable to a bankcard with a picture of the owner on it. WienMobil combines an annual PT ticket and access to both - a bike- and carsharing scheme. Additionally it offers its users the opportunity to pay taxis and use vehicles of a car rental company and gives fee reductions for the airport express train, for charging electric vehicles and for using certain car park facilities. The card has an annual price of 377 euro for an adult, which is one euro more per month than the price of the annual public transport ticket for the city of Vienna. Responsible was a task group comprised of different departments of the municipality utility holding of the city of Vienna (Wiener Stadtwerke).

\section{BACKGROUND, RESEARCH QUESTION AND METHOD APPLIED}

This article introduces lead users who have already bought the WienMobil card. Since the WienMobil card was launched just recently, we refer to this group as lead users. They are described with regard to socio-demographics, their mobility behaviour, and also their demands and attitudes concerning the WienMobil card and public transport in general. For comparison, a group of annual public transport ticket holders is used.

The results were obtained in the project Guide2Wear. The project deals with the mobilityrelated impacts of wearable devices such as smart glasses, smartphones or smartwatches with the final objective to develop an intermodal navigation application for a smartwatch. These innovations have to meet the demands of their supposed users to be both helpful and successful [10]. In order to create such an app, several initial analyses were conducted. They included expert workshops, focus group discussions with end costumers or a Delphi survey among mobility experts and developers of software and hardware in the fields of intermodal applications and wearable devices.

In order to analyse the impacts of the WienMobil card, a pre-post-control-group approach was applied. It included a Web survey and two GPS-tracking periods, each covering an entire week. A first tracking period took place in spring and summer 2016 before the WienMobil card was delivered to its buyers, and a second tracking stage took place in autumn 2015. The control group consists of annual public transport ticket owners since the WienMobil card is clearly an add-on to the annual public transport ticket - the price of the WienMobil card (377 euro/year) is one euro higher per month than the price of the annual ticket.

A letter was sent to all persons who ordered a WienMobil card in April or May and granted contact for research-related purposes. A total of 271 letters were sent out. The control group was contacted based on a list of 2.406 randomly selected persons. Since pupils, trainees and students up to 26 years get reduced tickets, but have to pay the full price for the WienMobil card, an age limit between 24 and 60 years (senior ticket) was introduced for the control group members. The gross sample accounted for 2.319 persons due to invalid address data. 441 persons had no annual public transport ticket and were thus not part of the target group. To 522 persons a contact could not be established by mail or phone (up to seven attempts per person) or a conversation was not possible. This results in an adjusted gross sample of 1.356 persons. 266 of them completed the questionnaire, resulting in a response rate of $20 \%$. The response rate for the lead users (90 participants) is $33 \%$. A weighting procedure was conducted based on public data from Statistik Austria using age and gender as variables. 130 persons belonging to the control group and 45 WienMobil cardholders tracked their mobility behaviour for at least one day using the modalyzer app developed by InnoZ GmbH. 


\section{RESULTS}

\subsection{Socio-demographics}

The mean value and the median of the age distribution of the participating lead user is 38 years. These values account for 34 years (mean) and 36 years (median) for all WienMobil card users. Members of the control group are older. The sample members' average age is 44 years, the median 45 years. The average age of all annual ticket holders is 39 years, the median 40 years. Mobility card users are younger than annual ticket users; this refers to both - our sample and the entire population.

$78.6 \%$ of the owner of the sample of WienMobil cardholders are male, while it was only $44.7 \%$ in the annual ticket users. These values account for $80 \%$ (WienMobil) and $41 \%$ (annual ticket) in the entire population. Thus, there is no clear picture with an above-average number of men in the control group, but there is below-average number among lead users. However, the differences are not pronounced.

The age and sex distribution implies no impact of the research method on the participation rate. It was assumed that the two-stage smartphone-based GPS tracking was a higher barrier for non-technophile persons and groups. It is said that technophile persons are more likely male and younger than in average, but this group is not overrepresented in our sample.

The average household size of the respondents is 2.3 persons per household. This value is the same for WienMobil cardholders and annual ticket holders. Significant differences $(p<0.01)$ appear in the age distribution of the household members. WienMobil cardholders have in average 0.26 persons younger than 18 years living in their household, while the responding value is 0.54 in the control group. $84 \%$ of the WienMobil cardholders live in households without children, while it is only $69 \%$ in the annual ticket holders.

The education level in the entire sample is higher than in the Austrian average. $75 \%$ of the WienMobil cardholders and $63 \%$ of the annual ticket holders have a general qualification for university entrance. In both groups, less than $10 \%$ have no or just a basic school graduation.

\subsection{Current mobility behaviour}

The participants were asked to indicate their perceived mobility behaviour (Fig. 1). Walking is the most often indicated mobility form. Three of four people walk (almost) daily and further $14 \%$ walk four or five times per week. This is followed by public transport for distances below 100 kilometres, which $81 \%$ of respondents use at least four times per week. This is no surprising result, taking into account the selection of the target group and the dense public transport network in Vienna. Other transport modes are rarely used such as public transport for trips above 100 kilometres or planes.

The respondents can be characterized as more or less monomodal based on their stated mobility behaviour. $70 \%$ use their own bike and $60 \%$ drive their own car less than once per week - although $87 \%$ have a car driver licence. Bikesharing and carsharing as well as rental cars are used only exceptionally: $94 \%$ of the respondents use bikesharing schemes less than once per month. The same applies to car rentals (89\% of the respondents).

However, there are clear group differences. Lead users stated to use bikes and cars - both their own and sharing/rental vehicles more often. For example, $18 \%$ of them use a bikesharing system or a rental bike at least once per month compared to $1 \%$ of the control group 


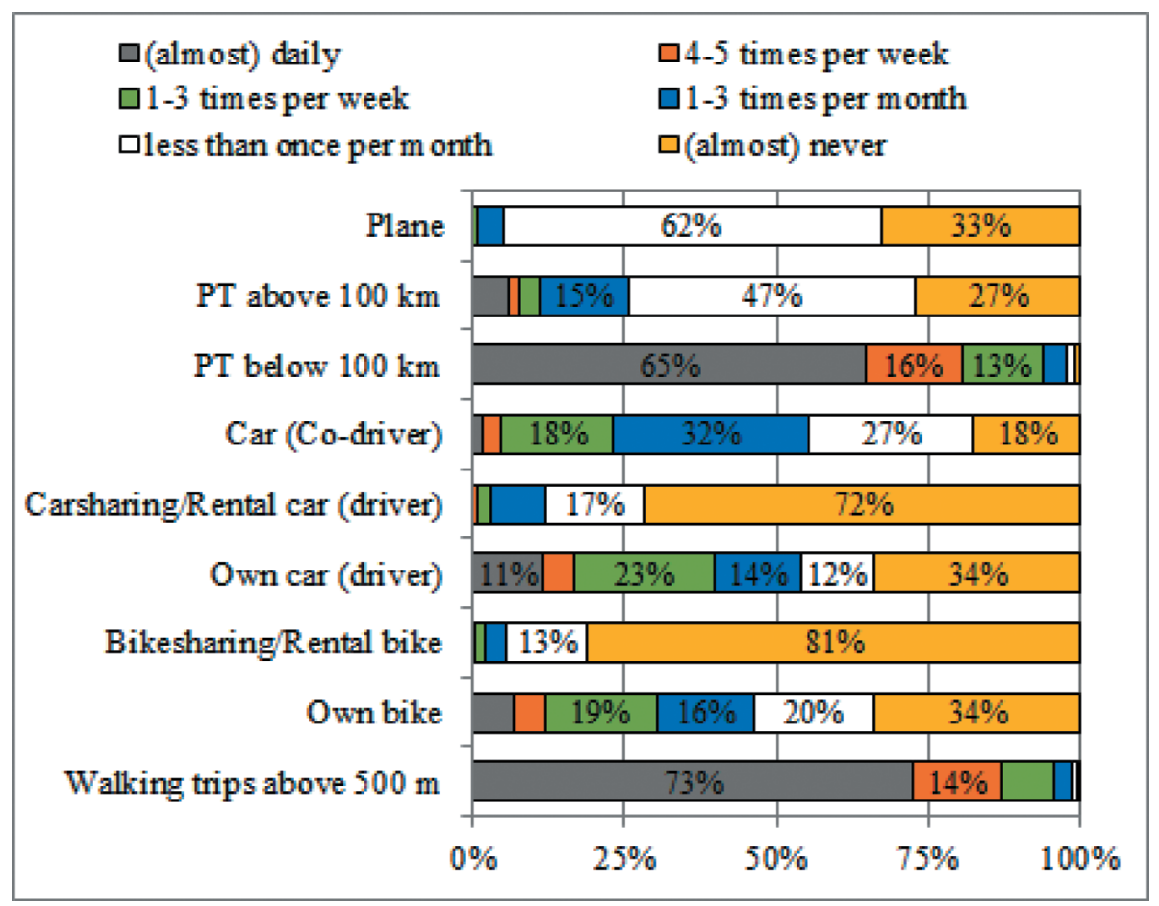

Figure 1: Reported mobility behaviour, $n=354$ persons.

members. $81 \%$ of the control group members, but only $42 \%$ of the lead users, never use carsharing systems. Control group members use PT more often according to their statements.

\subsection{Multimodality}

As mentioned before, there is no general accepted threshold to define multimodality. Multimodality can mean either to use several different mobility options within a short period of time such as a week or to use plenty of mobility options during a longer period of time such as a month. The share of multimodal persons is shown for different thresholds in Table 1.

The share of multimodal persons is between $0.5 \%$ and $34.7 \%$ of all respondents depending on the threshold. If it is set, for example, to four mobility options within one week - e.g. use of an own bike, a bike from a sharing system, at least one walking and public transport on a short-distance trip $-25.6 \%$ of all persons would be multimodal. If one additional mobility option has to be used at least once per month (such as a long-distance public transport trip), the share of multimodal persons drops to $16.3 \%$. Table 1 shows that a threshold focusing on monthly mobility behaviour and thus highlighting seldom actions results in high shares of multimodal people. As mentioned before, $34.7 \%$ of all persons are multimodal if the threshold is set on five mobility options per month, but only $16.3 \%$ of the additional (weak) limit of four options per week is set.

The share of multimodal persons is higher among WienMobil card users for all thresholds. This is not an impact of the WienMobil card itself, since the Web survey was conducted before the card was delivered to them. Thus, a mobility card might support inter- and 
Table 1: Share of multimodal persons depending on the threshold used.

\begin{tabular}{lcccc}
\hline \multirow{2}{*}{$\begin{array}{l}\text { Number of } \\
\text { mobility options } \\
\text { used per week }\end{array}$} & $\begin{array}{c}\text { Number of } \\
\text { mobility } \\
\text { options used } \\
\text { per month }\end{array}$ & All persons (\%) & $\begin{array}{c}\text { WienMobil } \\
\text { cardholders (\%) }\end{array}$ & $\begin{array}{c}\text { Annual ticket } \\
\text { holders (\%) }\end{array}$ \\
\cline { 3 - 5 } & 4 or more & 25.6 & 30.7 & 23.9 \\
4 & 5 or more & 5.9 & 7.0 & 5.5 \\
5 & 6 or more & 0.5 & 1.0 & 0.3 \\
6 or more & 5 or more & 34.7 & 45.4 & 31.0 \\
- & 6 or more & 11.6 & 19.6 & 8.9 \\
4 & 5 or more & 16.3 & 23.7 & 13.8 \\
4 & 6 or more & 6.6 & 14.2 & 4.0 \\
5 or more & 6 or more & 3.9 & 6.1 & 3.1 \\
\hline
\end{tabular}

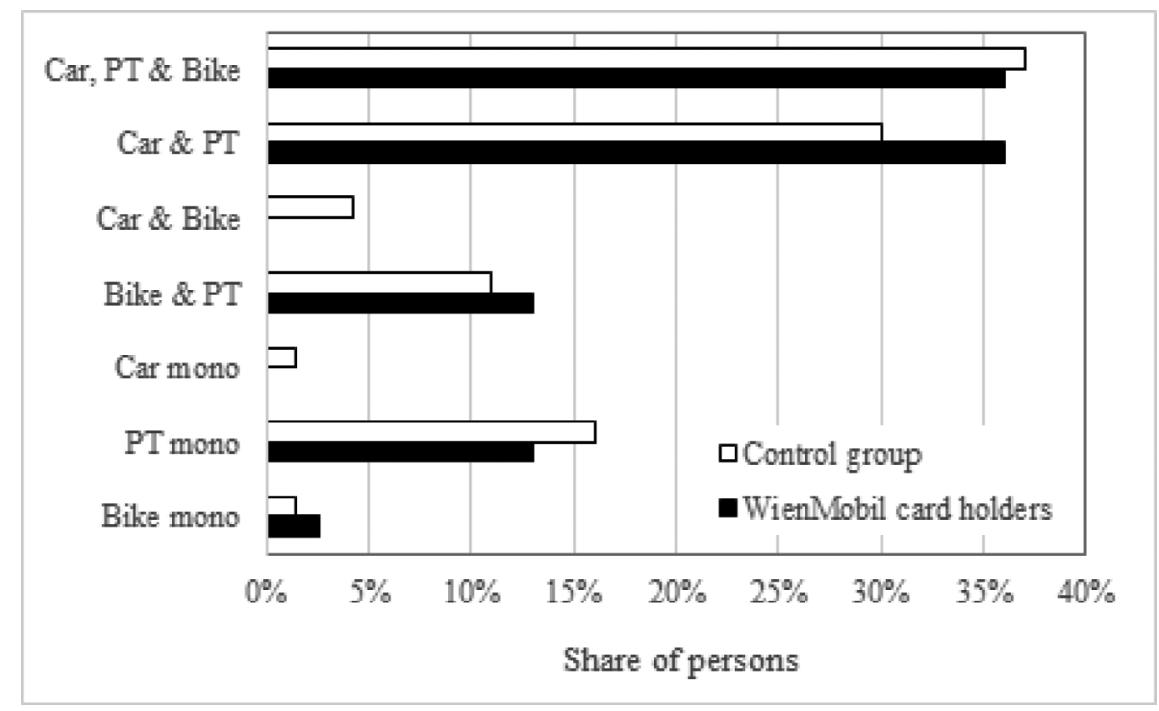

Figure 2: Measured mobility behaviour, $n=144$ persons.

multimodal mobility but there is also a self-selection process: buyers show this mobility behaviour already before the purchase.

Additionally, the mobility behaviour measured in the first tracking period can be taken into account (Fig. 2). In this figure, a transport mode is considered to be used by a person if he or she made at least $10 \%$ of his or her trips within the observation week with this transport mode. For example, a person with $60 \%$ PT trips, $32 \%$ car trips and $8 \%$ cycling trips is assigned to the category 'PT \& car'. Walking trips are disregarded. 
Almost $85 \%$ of the WienMobil cardholders and $82 \%$ of the control group members are multimodal if the threshold for multimodality is two transport modes per week. WienMobil cardholders are more often multimodal with regard to car and PT. In the categories bike and PT, and car and PT and bike are no clear differences, while more people of the control group use the combination car and bike. Overall, control group members are slightly more car oriented.

The GPS tracking was conducted before the WienMobil card was delivered. Thus, the mobility behaviour of the WienMobil card users is slightly more multimodal before they can use the card. This indicates that the purchase intention was made in order to support and extend an already shown mobility behaviour. It should also be noticed that the differences between both groups are small with regard to the GPS-tracking results compared to selfperception.

\subsection{Perception of public transport}

The respondents were asked if they agree with several statements concerning public transport. The highest level of consent was reached for the statement 'I intend to use PT in the next months' (96\% at least rather agree). Most people also consider using PT 'to be a good idea'. For both statements, the degree of consent is high which is not surprising, considering the target group of experienced PT users. There is also almost no group difference between lead users and control group members. PT is also considered safe and uncomplicated. The latter statement reaches a high level of consent of $93 \%$ in average (at least rather agree) and 94\% among lead users (Fig. 3).

More than $50 \%$ of all respondents regard themselves as totally or at least in most cases not bound to a certain transport mode. They see themselves free to choose, which is consistent with the fact that all of them own a PT ticket and most of them have access to a car. Lead users are less bound to a transport mode (71\% consent; control group: 64\%). Intermodality is perceived to be rather complex. It is annoying for $55.3 \%$ of all respondents, lead users and control group members to combine several transport modes on one trip.

There are only differences in detail between lead users and control group regarding the different statements. Both groups are highly PT affine, while lead users are expected to be more open to inter- and multimodality. However, this is not reflected in the statements given.

\subsection{Expectations and requirements concerning the mobility card}

Within the Web survey, questions were asked about the perception of the WienMobil card and mobility cards in general. $25 \%$ of the control group members intend to buy the WienMobil card. The most prominent argument (86\% of all answering persons) against a purchase is that the WienMobil card has no clear advantages for people without a driver's licence or a car. $68 \%$ of the control group members are in principle conceivable to buy a mobility card. Such a card would be attractive if it includes public transport (99\%), carsharing (79\%), bikesharing and rental bikes (79\%), reduced taxi fees $(66 \%)$ and a payment function for all mobility services $(66 \%)$.

The annual public transport ticket is, according to the lead users and the control group members with purchase intentions, the most important function of the WienMobil card. $100 \%$ of lead users and $97 \%$ of those with purchase intentions consider this function to be 


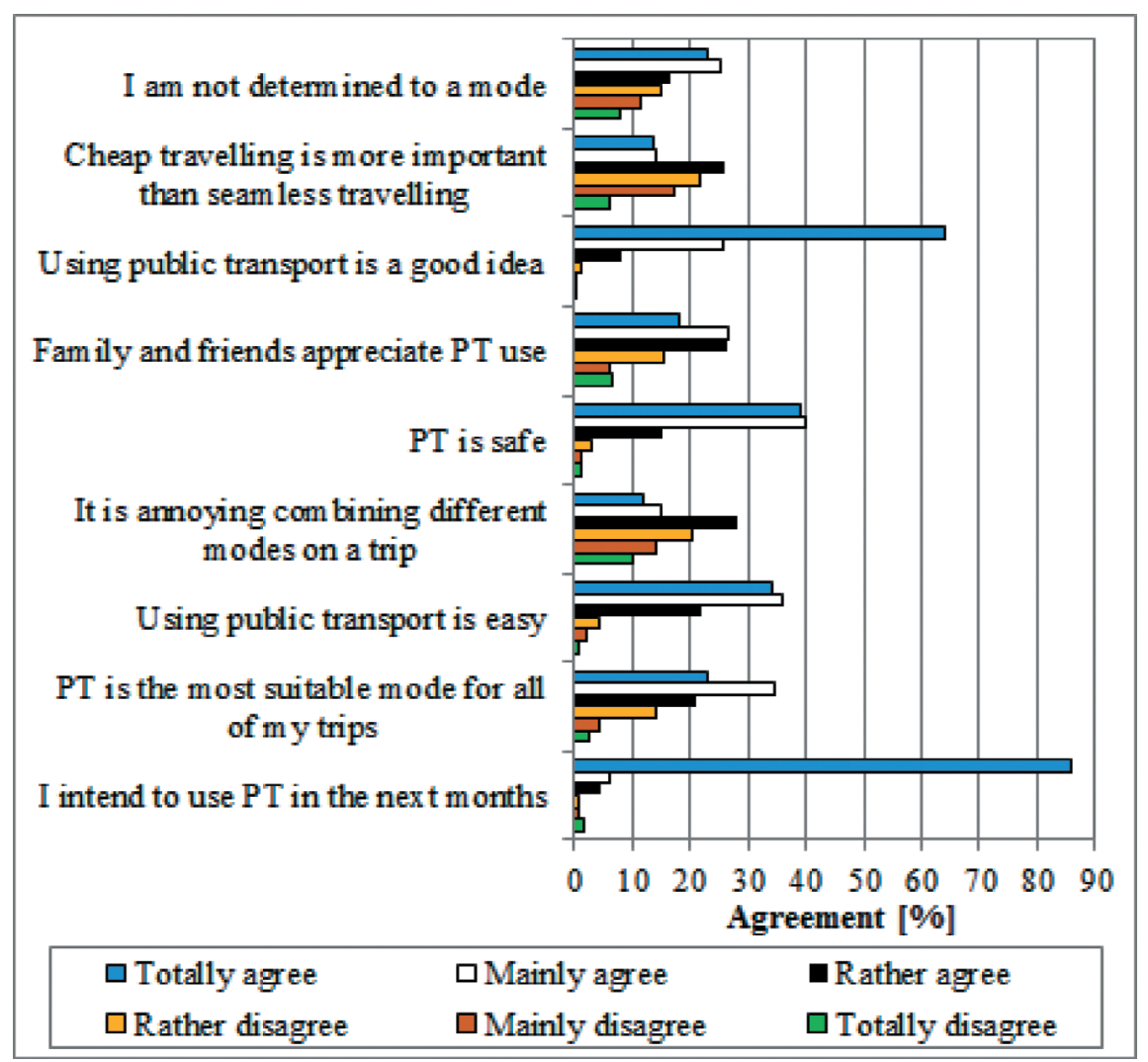

Figure 3: Perception of public transport, $n=354$ persons.

important (Table 2). This is followed by the integration of the bikesharing scheme. Charging of electric vehicles is not that relevant since nearly nobody has such a car.

A total of $12 \%$ of the annual ticket holders have purchase intentions for the WienMobil card and $15 \%$ of the lead users prefer the WienMobil card to be a physical card. $6 \%$ (annual

Table 2: Functions of the WienMobil card considered important (consent \%).

Function

Lead user (\%) Control group members with purchase intentions (\%)

Annual PT ticket

100

97

Bikesharing

65

57

Payment function: taxis

Reduced parking fees

Payment function: parking

Reduced charging costs for electric vehicles

20 
ticket holders and $10 \%$ of the lead users prefer an app instead of a card. Most persons would like to combine both an app and a card.

\section{CONCLUSION}

The WienMobil card is a mobility card that allows the use of several mobility options such as public transport, car- and bikesharing and car rental and offers further advantages such as reduced parking fees or cheap recharging of electric vehicles. It was introduced in spring 2015.

The study at hand is the first analysis of its impacts. A Web survey and a two-stage GPStracking study were conducted in 2015 . The control group consists of annual public transport ticket holders. Totally, 356 persons participated in the Web survey from which 90 were holders of the WienMobil card. The response rates were $33 \%$ for the WienMobil cardholders and $20 \%$ for the control group.

The lead users are younger and have a higher school education than control group members. They are more often male and have no children. Their mobility behaviour is to a higher degree multimodal. This refers to the measured mobility behaviour, but even more to the self-perception of their mobility behaviour. The difference is no effect of the WienMobil card itself, since the first tracking and the Web survey were conducted before the WienMobil card was delivered. Thus, multimodal persons tend to buy the WienMobil card which makes sense based on their mobility behaviour but is also an expression of their self-perception and thus also depending on lifestyle. Assessed by the consent to different statements concerning PT use, there are no clear differences between lead users and control group members. Both appreciate the opportunities offered by PT use, while lead users are more open towards intermodal mobility.

\section{ACKNOWLEDGEMENTS}

The research project Guide2Wear is funded within the Flagship Call 2013 of ERA-NET TRANSPORT III. Funding agency for the Austrian partners is the Österreichische Forschungsförderungsgesellschaft FFG. Project leader is Fraunhofer Institute for Transportation and Infrastructure Systems IVI.

\section{REFERENCES}

[1] Ahrens, G.-A., et al., Interdependenzen zwischen Fahrrad-und ÖPNV-Nutzung-Analysen. Strategien und Maßnahmen einer integrierten Förderung in den Städten, 2009.

[2] Stopka, U., Pessier, R. \& Fischer, K., User requirements for intermodal mobility applications and acceptance of operating concepts, Human-Computer Interaction: Design and Evaluation, 9169, pp. 415-425, 2015. DOI: 10.1007/978-3-319-20901-2_39.

[3] Dacko, S.G. \& Spalteholz, C., Upgrading the city: enabling intermodal travel behaviour. Technological Forecasting and Social Change, 89, pp. 222-235, 2014.

[4] Shaheen, S., Guzman, S. \& Zhang, H., Bikesharing in Europe, the Americas, and Asia: past, present, and future. Transportation Research Record: Journal of the Transportation Research Board, 2143: pp. 159-167, 2010. DOI: 10.3141/2143-20.

[5] Riley, P. \& Kumpoštová,A. Recommendations of the LINK project: European forum on intermodal passenger travel. in Proceedings of the European Transport Conference. 2010. Citeseer.

[6] Civitas. Introduction of the new urban mobility card: Brescia oMnibus card. Brescia, first city in Italy. 2011 [cited 2016]; Available from: www.civitas.eu/sites/default/files/ abstract-omnibus_card_brescia.pdf, accessed 10 April 2016. 
[7] Simhoffer, D. \& Oostrom, C., Utrecht Accessible Platform of cooperation between: Infrastructure authorities, Public Transport authorities and Trade \& Industry. 2012. Available from: www.civitas.eu/sites/default/files/presentation20ua.pdf, accessed 14 March 2016.

[8] Kleine, C. \& Natus, K., Ticket mobil in düsseldorf vereint bahn, bus, auto und fahrrad. tarifangebot setzt auf multimodalität und neues mobilitätsverhalten. Nahverkehr, 30(6), p. 14, 2012.

[9] Bestmann, D., Multimodale mobilitaet in Hamburg-switchh. Nahverkehrs-Tage 2013: Neue Konzepte für Stadt und Land, 24, p. 125-144, 2014.

[10] Gubbi, J., et al., Internet of Things (IoT): A vision, architectural elements, and future directions. Future Generation Computer Systems, 29(7) pp. 1645-1660, 2013. DOI: 10.1016/j.future.2013.01.010. 